\title{
キュビズム初期の絵画とフランス・モダニスト庭園に おける抽象表現の比較考察
}

\section{A Comparative Analysis of Two Abstract Expressions: An Early Cubist Painting and a French Modernist Garden}

村上修一*

Shuichi MURAKAMI

\begin{abstract}
摘要 : 20 世紀初頭のフランス・モダニスト庭園の意匠に, 当時の抽象芸術の一動向であるキュビズ ムの影響を指摘する議論がある。造形言語上の類似という指摘は多いが, 当初のキュビズム絵画を特 徵づける対象の抽象化が庭園においても同様に行われたかどうかについては十分に議論されていない。 この点を明らかにするために，表現対象の抽象化が強く現れているモダニスト庭園の一事例に着目し， その抽象化の仕方について, 初期のキュビズムにおける抽象表現との比較検証を行う。結果として, 当初のキュビズムとの共通点も認められるものの, 抽象化の仕方に違いがあることがわかった。
\end{abstract}

1.はじめに

1920 年代を中心にフランスで出現したモダニスト庭園 Modernist Garden' は，その空間構成や形態の特徵から，当時の抽 象芸術の影響が指摘されている。特に, 一連の抽象芸術運動の契 機となったキュビズムCubism の発生と展開の中心がフランス であったことから，しばしばキュビズムの絵画や彫刻との比較で 議論がなされてきた。フレッチャ一・スティール Fletcher Steele は, 当時の造園家アンドル・ヴェラ Andre Vera の空間 概念にキュビズムの影響を示唆し2)，ルグランLegrain 作の夕ッ カード邸庭園 Tachard Garden（1924）の平面構成を，キュビ ストの絵画同様に面白いと評した ${ }^{3)}$ 。マッケイン McCance とク ラーク Clarkは, キュビズムの絵画や彫刻の影響がある庭園と して数例を挙げている゙ 。ドロシー・インバートDorothée Imbert は，ゲヴレキアン Guvrekian 作ノアイユ邸庭園Villa Noailles（1927）の空間を分析し，キュビズムの絵画・レリー フ・家具との類似および相違を挙げて相関性を論じている ${ }^{5)}$ 。

これら仏モダニスト庭園に対するキュビズムの影響を論じた先 行研究には，キュビズムの造形言語が直接庭園空間に引用された とする見方が共通して存在する。マーク・トライブ Marc Treib の言葉を借りれば, キュビズムが生み出した空間概念や表現(多 視点場面の重なり合いや表現対象の再合成など)が庭園に実現さ れることはなく, むしろジグザグやピアノ曲線といったキュビズ ムの造形言語によって, 花壇・舗装・擁壁など庭園の構成要素が つくられた ${ }^{6>}$ とする見方である。

しかし，そもそあキュビズムとは，従来の再現的表現に対する 批判的精神のもと, 表現対象をいかに抽象化するかの探究よりは じまった動向である。特に, 分析時代と呼ばれるキュビズム初期 （1910 年前後）には, ピカソ Picasso やブラック Braque が, 静物や人物・風景といった対象を抽象化して表現することを試み 続けた。この時代におけるキュビスト達の絵画には, 彼等独自の 抽象化の仕方が共通しているように思える。

では，キュビズムの影響を受けたとされる仏モダニスト庭園に おいても，キュビズム的に対象を抽象化し表現する試みがあった のだろうか。インバートが明らかにしたように7)，キュビズム初 期に当たる 1910 年前後から 1920 年頃にかけてというのは, 庭園 においても様々な変化の生じた時期である。しかし，この時期の 庭園作品の中で, キュビズムのような抽象表現が視覚的に顕著な
例は認められない。むしろ顕著となるのは 1920 年代に入ってか らで, 特に 1925 年のパリ博という前衛的な試みを行いやすい環 境のもとでつくられた庭園作品群であり，その中には，キュビズ 么初期の試みとの共通性を強く感じさせるような, 対象の抽象化 が認められる事例があった。

その事例は，樹木を表現対象としているが，その視覚的特質を 大胆とむいえるほどに变換し抽象化している。その表現上の特徴 はキュビスト的な抽象概念の存在を強く意識させる。しかし，こ の作品はキュビズム初期と 10 年以上の時間的な隔たりがある。 また， 3 次元空間（庭園）と 2 次元空間（絵画）という違いや， コンクリートと画布・絵具という違い，すなわち表現媒体の差異 も存在する。そのため，本事例の抽象化は初期キュビスト達のも のと異なることも予想される。

本研究では，この作品における樹木という対象がいかなる視覚 特質上の操作を受けて抽象化されているのかという点について, 分析時代のキュビズム絵画における人物の抽象表現とと屯に比較 分析を行い，双方の共通点および相違点を抽出する。

2. Jardin de l'habitation moderne

分析の対象とする庭園 Jardin de l'habitation moderne（図 1.）は, 1925 年の 4 〜 月にパリで開催された万国装飾美術工 芸博覧会 ${ }^{8}$ で，庭園部門の作品として会場内に建設されたもので ある。この博覧会は, 卓越した自国の装飾工芸と, 第一次大戦以 後の完全なる復興を国際的にアピールしたいフランスのねらいが 背景にあり ${ }^{9)}$ ，当時フランスの装飾芸術で主流だったスタイル （後にアールデコ様式と呼ばれる）が強く現われる結果となった。 建築／家具／装飾／舞台・街路・庭園／教育という 5 出品部門 の内, 庭園部門（写真や図面による実作の展示む含む）において フランスのデザイナー達は, 伝統的庭園デザインからの脱却を試 みている。それらの多くは新素材や新技術を試すむのであったが, 空間の構成や表現媒体に抽象芸術の影響が明かに認められる作品 あ存在した。これらの作品はフレッチャー・スティールによって アメリカに紹介され，後世のランドスケープ・デザインを担うラ ンドスケープ・アーキテクト達を多いに刺激した ${ }^{10)}$ 。

この庭園はセーヌ川にかかるアレクサンダー三世橋をはさんで 南北に延びる博覧会場の左岸側に位置し，庭園内には高さ $5 \mathrm{~m}$ の 「キュビストの木 Arbres cubistes」と名付けられた ${ }^{11)} コ$ コリー

*京都大学大学院農学研究科 


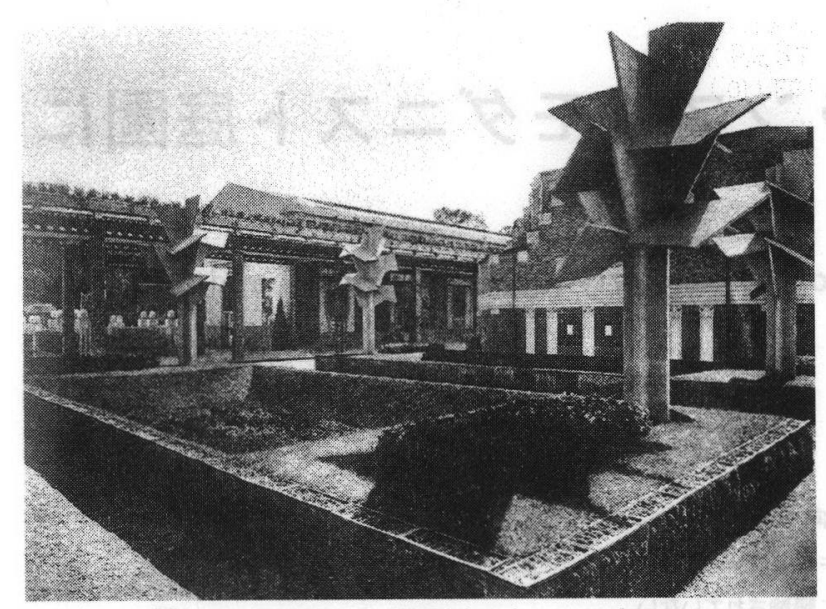

図-1 Jardin de l'habitation moderne Imbert, Dorothée (1993): "The Modernist Garden in France": Yale University Press より引用

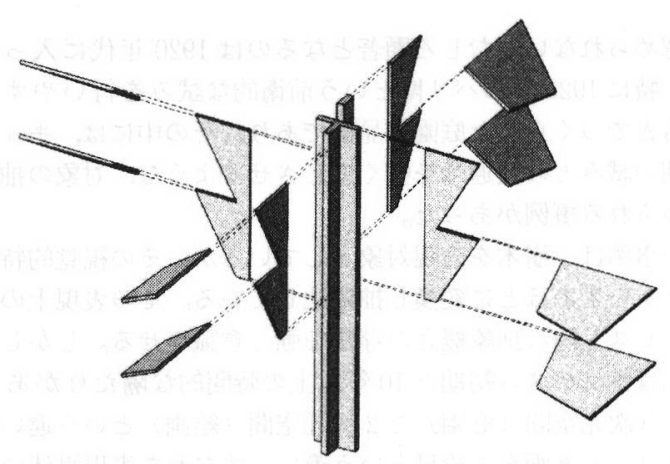

図－２「キュビストの木」分析図

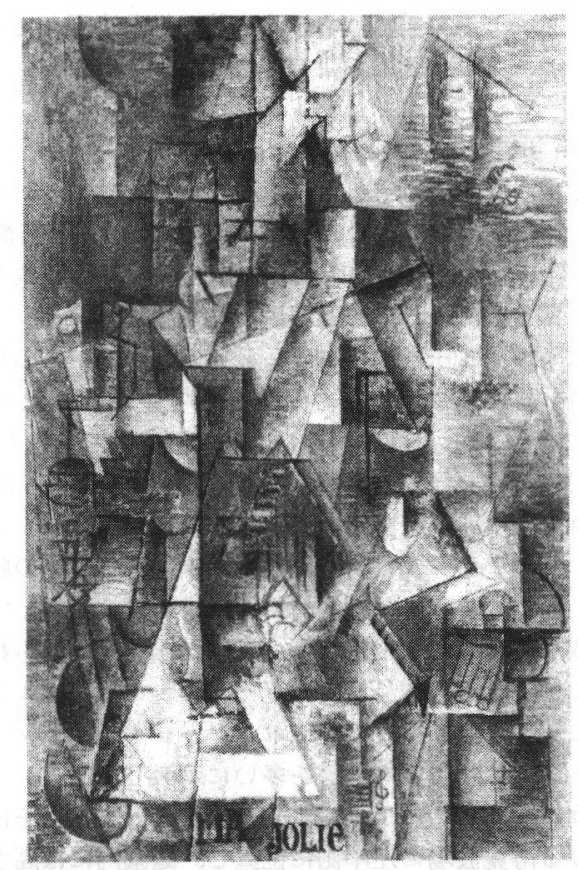

図-3 Ma Jolie (1912)

"Picasso and Braque-Pioneering Cubism" (1989): The Museum of Modern Art, New York より引用
ト製オブジェが 4 本屹立していた。盛り上げられた花壇に立つそ の柱の断面は十字型でジグザグの翼がせりだし, 約 $45^{\circ}$ 傾いた コンクリート板が 2 枚ずつ 4 方向に張り出していた。

庭園はフランス人建築家ロベール・マレニステヴァン Robert Mallet-Stevens (1886-1945) による設計であり，コンクリート 製の樹木はフランス人彫刻家マルテル兄弟（1896-1966）によっ て製作された。但し，このオブジェのアイディアはマレ・ステヴァ ンによるあのとされる ${ }^{12)}$ 。両者はコラボレートすることが多く, マレニステヴァンの設計による博覧会場の観光館でもマルテル兄 弟によってレリーフがつくられた。両者が実践を開始した 1910 年代は一連の抽象芸術がヨーロッパで急速に展開していった時期 にあたる。フランスではその展開の中心がキュビズムでありマル テル兄弟はまさにその流れの中にあった。一方，マレ＝ステヴァ ンは近代主義建築家として活躍した人物で, キュビズムの枠を越 えたところでの（例えばコルブジエ Le Corbusier, ドウースヴ ルク Théo Van Doesburg, マン・レイ Man Rayなど）人的 交流があった。

このコンクリート製樹木がつくられた直接の背景として, 会場 地下の埋設物により土厚が不十分であったこと, 施工期間が短い ため樹木が間に合わなかったといった問題への現実的対処であっ たという指摘むある ${ }^{13)}$ 。また形態の直接背景として, 博覧会に出 品されたフランス装飾芸術品に共通してみられる当時の流行様式 を指摘することは容易である。服飾やインテリアに応用された幾 何学形の面による意匠が特徴のそれらの中でも, 特にシャルー Chareau のランプは, 本事例の意匠と類似している ${ }^{14)}$ 。

コンクリート製の樹木に対する当時の反応は，単なるジョーク やうけねらいと決めつける者 ${ }^{15)}$, 水やりをすべきか? という風刺 画とともに挪揄する記事 ${ }^{16)}$ ，木を枯らしたための穿余の策とする 説, さらにはその奇抜な形態から宇宙の景観とする批評など様々 であった。日本における当時の紹介記事には「飴細工のやうな樹 木」萠とあり, 奇をてらうあのとして批判された。

\section{3. キュビストの木という抽象表現の考察}

作者であるマルテル兄弟がこのオブジェを樹木として製作して いることから ${ }^{18)}$, 樹木という現実のイメージがこの作品の表現対 象であることがわかる。だが, 現実の樹木の容姿とは明らかに異 なっており，樹木の視覚特質が操作された表現となっている。一 方, 比較対象とする絵画は, 分析時代キュビスト達の探究が極相 をむかえた時期の代表作であり，インバートの研究においても比 較対象としてとりあげられている，ピカソ作「マ・ジョリ $\mathrm{Ma}$ jolie (1912)」(図3) である。この絵画では人物が抽象化の対 象とされていて, 現実の人物のイメージとはほど遠い表現となっ ている。

キュビズム分析時代の抽象表現については, 実に多くの分析研 究や評論がなされてきた。それらに共通して存在し重要と思われ る見解を抽出し，比較分析の項目として設定した。それらの項目 は, （1）表現対象之表現行為の関係性,（2）形態の解体と純化, （3）空間感覚の拡張，(4) 図と地の相対化，（5）色彩の抑制，(6) 動態表現，（7）リアリズム，である。（1）表現対象および (7) リアリズムは, 視覚特質の操作を特徴づける直接の項目ではない が, 抽象化の仕方を左右する重要な要因であると判断して加えた。 (1) 表現対象ट表現行為の関係性

1907〜12 年頃のピカソやブラックは, 部屋の中にある静物や 人物・街の風景といった日常的なものばかりを描いた。マ・ジョ リの場合はギターを持った人物である。樹木という表現対象あ日 常的な対象という点で共通しているといえよう。

キュビズム初期に対象がこのように限られたのは, 表現を通し て語ることを避け象徴性の伝達を排しようとしたためだとする見 
方がある ${ }^{19)}$ 。たまたま作者の眼前にあったから表現したのであっ て, 表現対象之表現行為之の間には偶然的な関係しかないとされ る。マ・ジョリにおいて対象に対する作者の感情移入の有無は不 明であるが，コンクリート樹木の場合は表現行為の対象として選 ばれたのが偶然だとは思えない。なぜなら，フランスのみならず 庭園の伝統において庭園之樹木との必然関係は非常に強いためで ある。

\section{(2) 形態の解体と純化}

マ・ジョリの画面には輪郭線や色相のまとまりによって三角形・ 四角形といった幾何学図形が分布し, 対象がこれらの断片へ之解 体され表現されている。キュビズム初期の抽象化において表現対 象の形態は幾何学図形の面门解体された。コンクリート製樹木の 場合,「幹」「枝」「葉」(あるいは葉の群) 別に幾何学図形のコン クリート板で表現されている。複数の記録写真よりこの作品を $\mathrm{CAD}$ 上で再現し, 形態を図2.のように分解して表現してみた。 この図のように，「幹」は円柱でなく直交する 2 枚の細長い板, 「枝」は線でなくジグザグの輪郭をもった板であり，面的な幾何 学図形による表現へのこだわりが䂓え, キュビズム初期との類似 性が認められる。これらの面はマ・ジョリのように重なりあって 見えるのである。また, 形態純化の結果として本物の樹木に特徴 的な無数の葉が織りなす光と影のテクスチャーも純化され，コン クリート板と日光によって生じる大胆な明暗のコントラストとし て強調される。

一方, 相違点として, マ・ジョリの表現では対象の部位と解体 の単位である各断片とに，コンクリート製樹木のような明確な対 心関係がみられないということが挙げられる。同時期の別の絵画 では人物や静物の一部位が明確に分割された例もある。また，マ・ ジョリでは対象を断片化した各面の輪郭が完結していないため, 断片のひとつひとつを明確に区別することが難しいが，コンクリ一 ト樹木では各断片が明確に輪郭をむっており単体の区別が容易な ことも, 相違点として挙げられる。

\section{(3) 空間感覚の拡張}

キュビズム初期では絵画という2 次元媒体を通して現実の 3 次 元空間をいかに表現するかが探究された。マ・ジョリをみると表 現対象 (人体) の断片が重なりあう部分で, 本来は不透過なはず の人体が透けて見えるような表現がなされている。不透過のもの を写実的に 2 次元化すると後のものは前のものに檃れて見えない, という自然な空間感覚に対する懐疑的・創造的態度か認められる。 この試みは 2 次元媒体である絵画がゆえの所産である。

これに対し樹木の抽象表現の場合は媒体が現実空間であり本質 的に異なる。現実空間では時間の経過とともに（例えば視点を変 える）見え方が変わるのが自然な感覚である。コンクリート樹木 の形態は,このような感覚を変えようとの目論見を示唆する。こ の作品を複数の向きで再現してみたのが図 4.であるが, 視点を 変えることによって形態の本質があまり変化しない。それは，造 形言語を面に限定したため各部位の形態差異が少ないこと, 四方 均等な「枝」張りや「幹」の形態,「枝」や「葉」が鋭角を伴う矩形 であること，それに「葉」の傾きにより，オブジェのまわりを移 動するにつれて，「幹」を中心として「葉」や「枝」が明確に区
別できない状態で回転する見え方となるからである。

フレッチャー・スティールはこの作品を含むパリ博の庭園につ いて, 空間感覚を拡張するものとして評価しているが2010，この作 品についてはそうとはいえない。確かに，視点の変化によって見 え方が変らない形態を達成しているかもしれないが, それは, 現 実の樹木についても観察できることである。また，樹木のもつ葉 の細かいテクスチャーによる樹冠の透過性が，コンクリートとい う不透過の材料と大きさによって失われ，後のものが前のものに 隠れる感覚を強調してしまっていること屯指摘できる。この点で, キュビズム初期の試みのような自然な空間感覚に対する懐疑的・ 創造的態度が珰められにくい。

(4) 図と地の相対化

マ・ジョリの面面には断片が全体にわたって分布している。絵 画の場合，画面之表現対象の大きさ・形が一致しなければ，描か れる対象（すなわち図）之余白（すなわち地）という絶対的な関 係が現われるはずである。ところが，キュビズム初期の抽象化の 過程では図と地が同様に表現され相対化した。

表現対象と背景の相対化はこの庭園にみられない。むしろ逆の 関係が，図としての「キュビストの木」，地としての庭園との間 に成り立つ。第一に，眓はコンクリートの柱という垂直性の強い 形態特性をもち, 地は花壇・芝生・低木という水平な形態特性を もつ。第二に，図が無機質な素材であるのに対し，地は有機的な 素材である。これらの理由により，両者は対照的な視覚性質をも ち，絶対的な関係にあるといえる。

（5）色彩の抑制

キュビズム初期における抽象表現では，対象の色は二次的であ るかのようにモノクロに近い表現へとシフトしていった。コンク リート製樹木の場合, 着彩といった表面仕上げはされず, 素材そ のものの色によって表現されており，対象の色が抽象化の過程で 切り捨てられるという共通性がある。

\section{（6）動態表現}

マ・ジョリの各断片の形態特性（特に鋭角を伴うこと）や多方 向の集積は, 写実的な静物画や肖像画のような静態表現と反対に 動態的な表現をもたらしている。鋭角を伴う輪郭の「葉」が傾け て付けられていること，「幹」の頂部が不揃いであること，「枝」 の付けられる高さが四方それぞれ異なり,「葉」が螺旋状に高さ を変えて付いている，といった形態上のディテールにおいて，安 定さを嫌い動態表現に固執した作者の意困が䆓える。

(7) リアリズム

初期のキュビスト達が対象の抽象化を追い続けたのは, 真の現 実とは何かを問い続けた結果であり, 根底には現実への固執があ る。しかし, 探究の結果として到達したマ・ジョリのような表現 は彼等にとっての現実としては結局受け入れられない屯のであっ た。マレニステヴァンスやマルテル兄弟が同様に樹木の真の姿に こだわったかどうかは既存の資料からは読み取れない。だが一方 で，庭園をとりまく近代化という社会の大きな変化の現実を投影 するものであった。十分な土壌厚がなくとも「生育」することが できる無機物の「樹木」の存在は, 地下鉄や地中ヶーブルとい った地下埋設物という都市の近代化における環境変化を暗示す
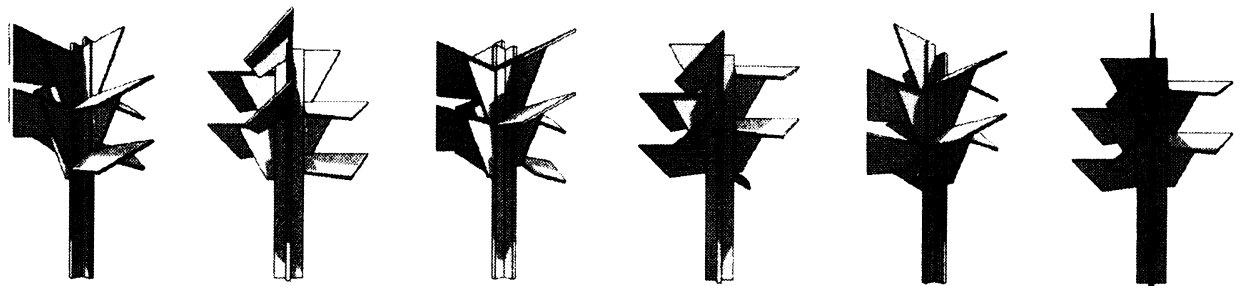

図-4＼cjkstart多視点からの「キュビストの木」の見え方
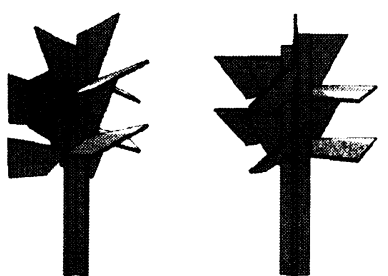
る。また, 取り替え可能な庭園部品としての「樹木」が 4 本屹立 する様は, 機械による規格化された製品の大量生産の時代を投影 する。

\section{4.おわりに}

以上の比較考察により, Jardin de l'habitation moderne というモダニスト庭園に抢ける対象の抽象化は, 分析時代にキュ ビストの試みた抽象化と，1)表現対象が日常的であること，2） 形態が幾何学図形の面に変換されること, 3 )対象の色は再現さ れず，無彩色の傾向にあること，4)動態的な表現となること， 5 ) 現実を反映すること, という点で共通していることがわかっ た。しかしその一方で，1)表現対象と表現行為に必然関係があ ること，2 )形態の変換が対象の各部位にとらわれていること, 3 ) 異次元性が認められにくいこと，4)図と地との間に絶刘的な 対照関係が成り立つこと，という相違点も認められた。

このような相違は, 庭園と絵画という本質的な相違に起因する ものなのだろうか。庭園という前提に関係なく表現対象を自由に 設定できたであろうし, 樹幹やキャノピーの部分が区別できない ように形態を変えてつくることもできたであろう。「樹木」以外の 部分も同じようにシャープなコンクリート面の集積によって構成 されていれば，庭園における図と地の関係は相対化したはずであ る。本事例の作家達は, 空間感覚に対する懐疑的な態度や創造性
を，分析時代のキュビストほど持ち得なかったのだろうか。他の モダニスト庭園事例についても検証の余地があるが，このような 相違点の背景について, キュビズムという動向が分析時代から 15 年ほどの間にどう変化していったのか, 1920 年代のデザイナー 達にとってキュビズムとはどのような動向を指していたのか, と いった広範囲の文脈を今後分析していく必要がある。一方, 本事 例以前の庭園についても, 視覚的に顕著ではないが, 概念レベル で影響したから゙うか明らかにされねばならない。

モダニスト庭園に対する抽象芸術の影響を論じるにあたって, 抽象芸術の所産である造形言語と庭園要素の形態との類似性や, 絵画と庭園におけるコンポジションの共通性を指摘することは, 非常に重要であることに変わりはない。それと同時に，絵画とい う領域で顕在化した抽象化の概念が，庭園という領域にどの程度 浸透し表現として結実したのか，という概念レベルでの抽象芸術 の影響を議論することも重要である。本研究は, 仏モダニスト庭 園の意匠に対する抽象芸術の影響という大きな課題に取り組んで いく端緒として，一事例における抽象概念を検証した。結果とし て取り組んでいくべき様々の問題が明らかにされた。今後は，モ ダニスト庭園における他の事例をとりあげ，その抽象表現や抽象 行為の抽出, および抽象芸術における表現との比較分析を積み重 ねていく所存である。

\section{補注・文献}

1) Imbert, Dorothée は20世紀初頭の仏庭園の 変化動向について “The Modernist Garden in France" (1993) : Yale University Press の中で詳細な研究を行っておうり, 動向の所産 である一連の庭園を総称して表題のように呼 んでいる。本論文でも同様の呼称を用いる。

2) Steele, Fletcher (1922): French Gardens and their Racial Characteristics : Landscape Architecture Quarterly 22(4), 1922:211$223:$ p.222

3) Steele, Fletcher (1929): New Styles in Gardening:Will Landscape Architecture reflect the Modernistic Tendencies seen in the Other Arts ?: The House Beautiful 65(3), 1929:317,352-353: p.353

4) McCance, William and Clark, H. F. (19 60): The Influence of Cubism on Garden Design : Architectural Design 30(3), March 1960, pp.112-117

5) Imbert, Dorothée (1993) : Still Lifes \& Abstract Gardens : The Modernist Garden in France: Yale University Press : pp.6369

6) Treib, Marc(1993): Axioms for a Modern
Landscape Architecture : Modern Landscape Architecture: A Critical Review : The MIT Press : p.47

7) Imbert, Dorothée (1993) : ibid. : pp.1-25

8) 原名 “Exposition Internationale des Arts Decoratifs et Industriels Modernes" に対 し 日本政府の参同事務報告書（昭和 2 年）で用 いられた訳語。「世界の新建築」Vol.9（大正 14 年, 本間乙彦編, 建築趣味社刊) では, 「現代装飾工芸博覧会」という訳語が使われ ている。

9) Siver, Kenneth E. (1989) : Esprit de corps: The Art of the Parisian Avant-Garde and the First World War, 1914-1925 : Princeton University Press : p.362

10)宮城俊作 （1994）: ランドスケープデザイン における近代主義の萠芽にはたしたフレッチャー ・スティールの役割：造園雑誌 57(5), 67-72

11) Veillot, Valerie (1996): Les freres Martel exposent aux grandes manifestations internationales de 1925, 1931 et 1937 : Joel et Jan Martel: Sculpteurs 1896-1966 : Galli mard / Electa : p.59

12) Pinchon, Jean-Francois : Rob. MalletStevens: Architecture, Furniture, Interior
Design : The MIT Press : p.64

13) Imbert, Dorothee : ibid. : p.38

14) Landry, Lionel (1925): Introduction a l' Exposition : Art et Decoration Vol.47, May 1925, pp.129-228 : p.156

15)Landry, Lionel : ibid. : p.212

16) Beauplan, Robert de (1925) : A Travers la Kermesse de Paris : L'Illustration, no.4307 (9. Sept.1925) : p.288の J. Touchetによる イラスト “Devant l'arbre cubiste: l'arroseur perplexe"。

17)本間乙彦編（1925）：世界の新建築 Vol.9： 建築趣味社, 8

18) Veillot, Valerie (1996) : Les freres Martel exposent aux grandes manifestations internationales de 1925, 1931 et 1937 : ibid. : p.59

19)Golding, John(1981) : Cubism : Concepts of Modern Art: Thames and Hudson: p. 61

20)Steele, Fletcher (1930): New Pioneering in Garden Design : Landscape Architecture Quarterly 20(3), Apr. 1930, pp.159-177: p. 161

Summary: There have been arguments about the influence of Cubism, one of the abstract art movements, upon the design of French modernist gardens in the early twentieth century. Those have tended to focus on the Cubistic vocabularies evident in the compositions of space and the forms of the garden elements. But, it has been hardly discussed if the same way of abstraction as that of the Cubists, who pursued how to abstract their "objects" in the analytical period, emerged in the realm of the garden design. In this discussion, an example of abstraction among the modernist gardens is comparatively analyzed with a Cubist painting. The result shows not only the resemblance but also the difference between the both ways of abstraction. 